\title{
Izborni sistem BiH i etnicizacija bosanskohercegovačkog političkog prostora
}

\author{
Elma Huruz Memović \\ Docentica Fakulteta političkih nauka \\ Univerziteta u Sarajevu \\ elma.huruz@fpn.unsa.ba
}

\begin{abstract}
Sažetak: Izborni sistem Bosne i Hercegovine se smatra specifičnim iz nekoliko razloga, a njegov sadržaj od samog uspostavljanja bio je do sada na različite načine problematiziran. Jedan od ograničavajućih faktora ovog sistema, koji je u suprotnosti s univerzalnim i jednakim pravom glasa, sadržan je u odredbi da je to pravo zasnovano na etničkoj pripadnosti. Pored toga, ograničenje ovog prava dodatno je pojačano činjenicom da je pravo kandidiranja usko limitirano mjestom prebivališta, odnosno entitetskim granicama. Političko predstavljanje u Bosni i Hercegovini je gotovo u potpunosti određeno i ograničeno principom konstitutivnosti koji dominantno etnički kroji bosanskohercegovački politički prostor onemogućujući na taj način uspostavljanje koherentnog društvenog i političkog tkiva u $\mathrm{BiH}$.
\end{abstract}

Ključne riječi: izborni sistem Bosne i Hercegovine, univerzalno i jednako pravo glasa, pravo kandidiranja, princip konstitutivnosti

\section{Uvod}

Bosanskohercegovačko društvo karakteriziraju dvije osnovne komponente, građanska i etnička. Te dvije komponente definiraju Bosnu i Hercegovinu kao državu koja je istovremeno „država svojih građana, ali i država ravnopravnih naroda koji u njoj žive - bošnjačkog, hrvatskog i srpskog, te pripadnika ostalih naroda“" (Pejanović, 2005:235). Političko-ustavna ravnopravnost ta tri naroda historijski se može pratiti od odluka Prvog zasjedanja ZAVNOBiH-a 1943. godine, referenduma o političkoj nezavisnosti i suverenosti države Bosne i Hercegovine pa sve do Odluke Ustavnog suda $\mathrm{BiH}$ o konstitutivnosti naroda.

Pojam ,konstitutivnost ${ }^{1}$ naroda“ nije dovoljno poznat niti često korišten unutar političkih nauka i u ustavnopravnoj literaturi. Kako se pojavljuje

\footnotetext{
${ }^{1}$ Termin „konstitucija“ izvodi se iz latinske riječi constitutio što znači uredba, ustroj, ustrojstvo dok constitutus pak znači „,sazdan“. Tako bi se termin „,konstitutivan“ mogao prevesti s „tvoran“ ili „tvoriteljski“, „,ili deskriptivno 'onaj koji nešto tvori, čini'. Tako bi 'konstitutivni narodi' jedne državne zajednice bili oni koji je tvore, odnosno od kojih je socijalna kvitesencija te države 'sazdana'“ (Seizović, 2012:29).
} 
problem diskriminacije nacionalnih manjina tako se u građanskim demokratijama multinacionalnih država razvija sistem zaštite koji najprije obuhvata garantiranje ljudskih prava i sloboda a, u pojedinim slučajevima, kao što je to slučaj sa Švajcarskom, Kanadom i Belgijom, i federalizacijom te davanjem određene mjere autonomije. U zemljama poput bivšeg SSSR-a, Čehoslovačke te Jugoslavije bio je zastupljen tzv. nacionalni federalizam te institucije kao što su „Dom naroda“ i „Vijeće nacionalnosti“ kao ustavna teorija i praksa kojom se težilo postići nacionalna ravnopravnost. Ipak, kako zaključuje profesor Kasim Trnka, na kraju su se ti potezi pokazali kao nedostatni budući da se „samo institucionalnim i državnopravnim reformama ne može rješavati pitanje nacionalne ravnopravnosti“ (2000:47).

Nurko Pobrić, unutar svoje analize studije „Bosna i Hercegovina, federalizam, ravnopravnost i održivost: Studija preustroja $\mathrm{BiH}$ u cilju osiguranja institucionalne jednakopravnosti konstitutivnih naroda" $\mathrm{u}$ izdanju Instituta za društveno-politička istraživanja Mostar 2016. godine sa urednicima Ivanom Vukoja i Milanom Sitarski, pojašnjava pojam konstitutivnosti. Slijedeći politološko tumačenje, on konstitutivnost određuje kao ,sposobnost jednog naroda da bude autorom ustava $u$ vidu samoodlučivanja i samostalnog djelovanja u oblastima relevantnim za očuvanje njegove konstitutivnosti, ali i suodlučivanja na ravnopravnim osnovama s drugim konstitutivnim subjektima u pitanjima od zajedničkog interesa“" (Pobrić, 2016:8). S druge strane, u navedenoj Studiji Vukoje se konstitutivnim narodima daje atribut suverenosti i državotvornosti uz argumentaciju da im te atribucije pripadaju s obzirom na historijsko-politološku, ali i voluntarističku dimenziju koja se odnosi na opredjeljenje konstitutivnih naroda da očuvaju državu.

\section{Nacionalna ravnopravnost u Bosni i Hercegovini}

Bosna i Hercegovina ima dugu tradiciju nacionalne ravnopravnosti. Prema članu 3. Ustava SFRJ iz 1974. godine „Socijalistička republika je država zasnovana na suverenosti naroda i na vlasti i samoupravljanju radničke klase i svih radnih ljudi,.... “. ${ }^{2} \mathrm{BiH}$ je definirana kao: ,socijalistička demokratska država i socijalistička samoupravna demokratska zajednica radnih ljudi i građana, naroda Bosne i Hercegovine - Muslimana, Srba i Hrvata, pripadnika drugih naroda i narodnosti koji u njoj žive“. U Ustavu se naglašava: „Povezani u svojoj prošlosti zajedničkim životom, stremljenjima i borbom za slobodu i socijalni progres, savlađujući nastojanja i slamajući otpore tuđinskih sila

\footnotetext{
${ }^{2}$ Ustav SFRJ iz 1974. godine, Osnovna načela, poglavlje I, „Službeni list SFRJ“ br. 3/74.
} 
i domaćih reakcionarnih snaga, našli su se prvi put slobodni, ravnopravni i zbratimljeni u svojoj republici, koja je postala društveni i politički oblik njihove povezanosti, međusobne ravnopravnosti, kao i ravnopravnosti sa ostalim narodima i narodnostima Jugoslavije sa kojima su se na osnovu prava na samoopredjeljenje, uključujući i pravo na otcjepljenje, dobrovoljno udružili u zajedničku državu - Socijalističku Federativnu Republiku Jugoslaviju...".3 Iz navedenog možemo zaključiti da je Bosna i Hercegovina tronacionalna država u kojoj svoja prava ostvaruju tri naroda koji je čine, ,zajednički i u međusobnoj povezanosti sa ostala dva naroda“ (Trnka, 2000:49). Jednako kao što su jednonacionalne, tako je i Bosna i Hercegovina, tronacionalna država, prema navedenom Ustavu imala pravo na samoopredjeljenje i pravo na secesiju budući da se dobrovoljno i sporazumno prethodno udružila sa drugim republikama tvoreći saveznu državu Jugoslaviju.

Pojam „konstitutivni narodi“ se nije izričito koristio u ustavima socijalističkih zemalja te ga, kao ustavnu kategoriju, nalazimo prvi put u Ustavu Federacije $\mathrm{BiH}$ a nakon toga u Ustavu $\mathrm{BiH}$ iz 1995. godine. „U sintagmi 'konstitutivni narod', riječ 'narod' je upotrijebljena u smislu nacije, odnosno posebnog nacionalnog identiteta, a ne naroda (populus-a) kao zbira pojedinaca, pripadnika jedne države, pojam 'konstitutivan' u etimološkom smislu znači osnovni, sastavni, temeljni, bitan, koji određuje“" (Trnka, 2000:50). Sama riječ „konstitutivan“ proizilazi iz latinske riječi „constitutio“ koja u svojem glagolskom obliku znači postaviti, urediti, osnovati, ustanoviti dok kao imenica označava: unutrašnju strukturu, organizaciju, uređenje, ustav, zakon, ustanovu (političku). ${ }^{4} \mathrm{U}$ francuskom jeziku riječ ,,constituant“ znači ustavotvoran, osnovni, sastavan a glagol „constituer“" se prevodi kao ustanoviti, sačinjavati, osnovati $^{5}$. Na tragu ovih varijanti prevoda i značenja pojedini autori tvrde da je neophodno napraviti distinkciju između „konstituentni““ i „konstitutivni“ narodi te da je u prvom slučaju riječ o ustavotvornom, državotvornom narodu, „odnosno o onom bez koga se ne može donijeti ili promijeniti ustav“, za razliku od drugog pojma gdje se ,radi o narodu koji je osnovni, sastavni dio nekog društva ili države“ (Trnka, 2000:50). Upotreba pojma „konstitutivni

\footnotetext{
${ }^{3}$ Prvo poglavlje Osnovnih načela i član 1. Ustava SRBiH iz 1974. godine objavljenog u „Službenom listu SRBiH“" br. 4/74.

${ }^{4}$ Grujić, Branislav: Rječnik latinsko-srpskohrvatski, Cetinje: izdanje Obod

${ }^{5}$ Kada je riječ o korištenju pridjeva konstitutivan (sastavni) se u engleskom jeziku je u upotrebi riječ „,constitutive“, „constituent“, „,component“, ,,constitutive nations“; u njemačkom jeziku „,konstitutiv“,, „konstituierend“, „grundlegend“, „rehtsbegruned“, „konstituirende Nacionen“; u francuskom jeziku „,constituant“, „constitutif“, „,nationes constitutives“ (Osmojezični enciklopedijski rječnik, knjiga 2, Zagreb: Leksikografski zavod „Miroslav Krleža“, 1995. godina)
} 
narod“ adekvatna je samo u višenacionalnim zajednicama ili državama u kojima niti jedan od naroda, odnosno nacija nemaju natpolovičnu većinu.

Važeći Ustav Bosne i Hercegovine je obezbijedio konstitutivnim narodima veća kolektivna nacionalna prava nego pripadnicima nacionalnih manjina budući da su prvi obavezno zastupljeni u strukturama državnih institucija te u odlučivanju u njima. „Sam princip 'konstitutivnosti naroda' je pojačan i razrađen u mnogim odredbama Ustava, gdje se čak ni formalno ne spominju 'ostali' ili 'građani'. Sastav svih zajedničkih institucija (Parlamentarna skupština, Predsjedništvo, Vijeće ministara, domaći suci Ustavnog suda Bosne i Hercegovine, itd.) utemeljen je na formuli 'jedna država, dva entiteta - tri naroda', što je, čini se, unikatan koncept u teoriji i praksi ustavnog prava i političkih sistema u svijetu i kao takav, neodrživ“ (Seizović, 2012:33). Iako u određenim slučajevima postoje velike razlike u poglednu brojnosti i udjelu u cjelokupnoj populaciji, te se razlike ne primjenjuju u pogledu zastupljenosti i pravu odlučivanja te se traži nacionalni konsenzus. Konstitutivni narodi, za razliku od nacionalnih manjina, imaju pravo donošenja odluka u vezi s izmjenama ustava te je njihov jezik i pismo ustavom definiran kao službeni.

Ustavno uređenje $\mathrm{BiH}$ je u svojoj građanskoj dimenziji ojačano prihvatanjem najviših međunarodnih standarda ljudskih sloboda i prava čime se garantira ravnopravnost građana u pravima i dužnostima kao i zabrana diskriminacije po bilo kojoj osnovi. Integralni dio Ustava čini Evropska konvencija o zaštiti ljudskih prava i temeljnih sloboda koja ima prvenstvo primjene u odnosu na domaće zakone. Ova konvencija, između ostalih, garantira pravo učešća svim građanima u ostvarivanju biračkih prava i učešća u državnoj vlasti bez diskriminacije po bilo kojem principu. Ipak, ,ravnopravnost naroda kako je propisana Dejtonskim ustavom i kakva se provodi u etnopolitičkoj praksi u $\mathrm{BiH}$ za nužnu posljedicu ima najgrublju neravnopravnost građana, odnosno flagrantnu diskriminaciju individualnih prava i sloboda“, tvrdi Mujkić (2007:157). Zapravo, jedina ravnopravnost koja djelatno funkcionira je „ravnopravnost etnopolitičkih oligarhija“, odnosno politički i interesni balans etnopolitičkih elita, zaključuje Mujkić.

\section{Princip konstitutivnosti i političko predstavljanje u institucijama Bosne i Hercegovine}

Građani Bosne i Hercegovine direktno biraju zastupnike Predstavničkog doma Parlamentarne skupštine BiH, Predstavničkog doma Parlamenta Federacije $\mathrm{BiH}$ te Narodne skupštine RS kao i poslanike u kantonalnim i općinskim 
vijećima. Na osnovu člana IV (stav 3.e) Ustava Bosne i Hercegovine „predložena odluka Parlamentarne skupštine može biti proglašena destruktivnom po vitalni interes bošnjačkog, hrvatskog ili srpskog naroda većinom glasova iz redova bošnjačkih, hrvatskih ili srpskih delegata..." "6. To je mehanizam koji manjina može upotrijebiti kao zaštitu vlastitih nacionalnih interesa pri čemu nije preciznije određeno šta sve obuhvata pojam vitalni nacionalni interes te je tako prisutna prilično slobodna i rastezljiva interpretacija. Procedura koju Ustav $\mathrm{BiH}$ u istom članu nalaže je da, kada se neka predložena odluka proglasi destruktivnom za vitalni nacionalni interes jednog od konstitutivnih naroda, ,za donošenje takve odluke bit će potrebna saglasnost Doma naroda, izglasana od strane većine bošnjačkih, većine hrvatskih i većine srpskih delegata koji su prisutni i glasaju“. Predsjedavajući Doma naroda treba onda da sazove tročlanu komisiju delegata paritetnog sastava kako bi pokušali usaglasiti stavove, ako to ne uspije onda se predmet upućuje Ustavnom sudu na preispitivanje. Ustav Federacije $\mathrm{BiH}^{7}$ također sadrži član koji definira zaštitu vitalnog nacionalnog interesa, no, ustavna formulacija je u ovom slučaju tako široko postavljena da se gotovo svako pitanje može proglasiti bitnim za vitalni nacionalni interes što je nerijetko u političkoj praksi bilo zloupotrijebljeno.

Iako su pripadnici ostalih naroda navedeni u Ustavu jednako kao i konstitutivni narodi njihova kolektivna nacionalna prava nisu posebno zaštićena, izuzev Ustavom Federacije BiH koji im osigurava predstavljenost u Domu naroda Parlamenta Federacije dok su za njih međunarodnim pravom predviđena kolektivna prava manjina.

Postojeći Ustav $\mathrm{BiH}$ je osigurao zastupljenost u državnim institucijama svim konstitutivnim narodima a na raspolaganju im je i efikasan mehanizam zaštite nacionalnih interesa u procesu donošenja odluka. S druge strane, građani koji se ne izjašnjavaju kao pripadnici jednog od tri konstitutivna naroda lišeni su pasivnog prava glasa, nemaju pravo učešća u javnim poslovima te im javne funkcije nisu jednako dostupne. „Nejednak tretman 'konstitutivnih naroda', 'ostalih' i 'građana' u BiH je u potpunoj suprotnosti sa ustavnom odredbom o zabrani diskriminacije“ a ljudska prava su zamijenjena kolektivnim koja se realiziraju isključivo na osnovu pripadanja grupi odnosno grupnog, nacionalnog identiteta (Nadaždin Defterdarević, 2014 :78).

\footnotetext{
${ }^{6}$ Ustav Bosne i Hercegovine, http://www.ccbh.ba/public/down/USTAV_BOSNE_I_HERCEGOVINE_bos.pdf, pristup 3. 12. 2017.

${ }^{7}$ Član 70, koji je dopunjen Amandmanima LIX, CVII, LXXVII i LXXXII na Ustav Republike Srpske, na identičan način kao Ustav Federacije BiH, definirao je pitanja koja reguliraju vitalni nacionalni interes konstitutivnih naroda.
} 
„Konstitutivnost naroda“" se kao termin prvi put pojavljuje u Mišljenju br. 2 Arbitražne komisije Evropske komisije Evropske zajednice iz 1991. godine koje spada u međunarodno-pravne dokumente. Arbitražna komisija je, nakon odbijanja prvog evropskog plana za rješavanje krize u bivšoj Jugoslaviji od strane Srbije i Crne Gore, imala zadatak da razmotri najsloženija politička i pravna pitanja u procesu disolucije SFRJ. Jedno od takvih pitanja koje je uputila Republika Srbija glasilo je: „Da li srpsko stanovništvo iz Hrvatske i Bosne i Hercegovine kao konstitutivan narod Jugoslavije uživa pravo na samoopredeljenje?“‘. Komisija je, nakon konsultiranja i pribavljanja odgovora od ostalih republika bivše Jugoslavije, Predsjedništva SFRJ i tzv. „Skupštine srpskog naroda $\mathrm{BiH}^{\prime}$ dala odgovor u kojem ne koristi pojam „konstitutivni narod“ nego „konstituentna grupa“. Kasim Trnka (2000:30) smatra da je lošim prevodom sa francuskog jezika umjesto pojam „konstituentna“ upotrijebljen pojam ,konstitutivan“, pojam koji se bitno razlikuje od prvog, u teorijskom i praktičnom smislu. Ipak, svi mirovni planovi koji su slijedili su koristili pojam „konstitutivnost" neovisno o tome da li se veže za pojam naroda ili teritorijalne jedinice u Bosni i Hercegovini.

Nakon početka rata u $\mathrm{BiH}$ uslijedilo je nekoliko mirovnih planova, jedan od prvih koji je nastao u okviru Konferencije o Jugoslaviji bio je Kutiljerov plan. Pregovore su, pod vođstvom portugalskog dipomate Kutiljera, vodili lideri tri vodeće parlamentarne nacionalne stranke u periodu od februara do augusta 1992. godine. Tom prilikom su kao osnova za dalje pregovore, do kojih nikada nije došlo, usvojena dva dokumenta. „Izjava o principima za novo ustavno uređenje $\mathrm{BiH}^{\text {“ }}$ predviđa formiranje tri konstitutivne jedinice zasnovane na nacionalnom principu, uz uvažavanje ekonomskih, geografskih i drugih značajki. „Osnovna vodilja ovog dokumenta“, smatra K. Begić, ,jeste da se nasilno uvede dominantna etnička komponenta i da, na toj osnovi, preko noći ukupno ustavno i teritorijalno ustrojstvo poprimi etnički predznak, čime je otvoren 'sukob' i sa tradicijom identiteta $\mathrm{BiH}$, na jednoj strani, a isto tako i sa standardima savremenih demokratskih društvenih zajednica u domenu ljudskih prava i građanskih sloboda, na drugoj strani“ (Begić, 1997:96).

Budući da je nakon neuspjeha Kutiljerovog plana bilo jasno da primjena nacionalnog kriterija nije adekvatan kriterij u traženju rješenja za $\mathrm{BiH}$, nakon održane Londonske konferencije o Jugoslaviji 26. augusta 1992. godine, na pregovorima u Ženevi iste godine početo je sa profiliranjem VanceOwenovog plana. Ovaj plan se distancira od principa etničke podjele te se bazira na uspostavljanju deset provincija koje bi bile zasnovane na geografskim, ekonomskim i drugim kriterijima. Pri tome provincije ne bi bile 
nazivane „konstitutivnim jedinicama“ niti bi se vezale za pojam „konstitutivnih naroda“. Pitanje nacionalne ravnopravnosti se posmatra i kao kolektivno i individualno pravo za čiju zaštitu bi bili zaduženi brojni domaći i međunarodni mehanizmi. Planom se također zahtijeva da budući ustav konkretno odredi šta se sve može podvesti pod pojam ,vitalni nacionalni interes“.

Owen-Stoltenbergov plan je ponuđen nakon odbijanja Kutiljerovog plana od strane „Republike Srpske“ a njime je predviđena apsolutna primjena nacionalnog kriterija, uspostavljanje nacionalnih republika, ukidanje državnosti $\mathrm{BiH}$ koja bi bila pretvorena u labavu uniju bez bitnih nadležnosti. Pri tome, umjesto ustava bio bi donešen ,ustavni sporazum u uniji tri nacionalne republike“ (Trnka, 2000:34). Owen-Stoltenbergov plan također predviđa teritorijalizaciju za svaki konstitutivni narod tako da bi svaka republika bila mononacionalna. Budući da evropski mirovni planovi, koji su se bazirali na nacionalnom kriteriju, nisu bili prihvaćeni, angažman SAD-a se distancirao od njega pri tome se pridržavajući demokratskih standarda, očuvanje državnog kontinuiteta te multietničkog fakticiteta Bosne i Hercegovine. U tom duhu su koncipirani i Washingtonski i Daytonski sporazum.

Specifična društvena odlika Bosne i Hercegovine kao višenacionalne i viševjerske države nalazi se u činjenici da je njeno stanovništvo oduvijek bilo izmiješano te se nije, sukladno nacionalnoj i vjerskoj pripadnosti, teritorijalno diferenciralo. Međusobna upućenost bosanskohercegovačkog stanovništva posebno je došla do izražaja tokom Drugog svjetskog rata kada je ideja antifašizma potvrdila princip bratstva i jedinstva svih naroda. U Rezoluciji ZAVNOBiH-a kao najvišeg predstavničkog tijela za Bosnu i Hercegovinu 1943. godine princip jednakosti i ravnopravnosti naroda najodlučnije je istaknut riječima da narodi $\mathrm{BiH}$,hoće da njihova zemlja, koja nije ni srpska, ni hrvatska, ni muslimanska, nego i srpska i muslimanska i hrvatska, bude slobodna i zbratimljena Bosna i Hercegovina u kojoj će biti osigurana puna ravnopravnost i jednakost svih Srba, Muslimana i Hrvata“. Kategorija slobode naroda i građana dodatno je potcrtana na Drugom zasjedanju ZAVNOBiH-a 1944. godine gdje je istaknut zajednički karakter domovine te njena nedjeljivost te takstativno nabrojana individualna, građanska prava od slobode vjeroistopovijesti do prava na neposredno i tajno glasanje.

$\mathrm{Na}$ samom početku agresije na Bosnu i Hercegovinu, kada su članovi Predsjedništva $\mathrm{BiH}$, delegati iz reda Srpske demokratske stranke (SDS) Nikola Koljević i Biljana Plavšić napustili tu najvišu državnu instituciju s namjerom delegitimacije vlasti, građanski multietnički opozicioni politički blok je tu situaciju izgladio dajući kandidate srpske nacionalnosti iz vlastitih redova. 
Zauzvrat je trebala biti donesena politička platforma o djelovanju vrha države u ratnim uslovima. „Ideja donošenja Platforme imala je za cilj izgraditi konsenzus unutar Predsjedništva $\mathrm{RBiH}$ o tome kakvu Bosnu i Hercegovinu žele njeni građani i narodi i za kakvu Bosnu i Hercegovinu se žele boriti patrioti iz svih bosanskohercegovačkih naroda“ (Pejanović, 2005:68).

Platforma Predsjedništva Bosne i Hercegovine u ratnim uslovima bila je „,najširi politički okvir za okupljanje svih patriotskih snaga, kao idejni projekt očuvanja i odbrane zemlje, bila je antifašistički intoniran, političko ustavni projekt viđenja budućnosti države“ (Filandra, 2012:244). Ovaj dokument je obuhvatao ideje i principe ravnopravnosti koji proizilaze iz multietničke strukture Bosne i Hercegovine te je potvrdio odluke prvog zasjedanja ZAVNOBiH-a iz 1943. godine. To se najprije odražavalo u formulaciji Bosne i Hercegovine kao građanske republike odnosno „države građana“ a onda i konstitutivnih i ravnopravnih naroda, Muslimana, Hrvata i Srba kao i pripadnika ostalih naroda. Dokumentom je definiran i unutrašnji ustroj države koje treba da počiva na principima regionalne i lokalne samouprave pri tome uvažavajući kulturne, istorijske i etničke specifičnosti. U platformi se naglašava da je suprotno interesima države pristajanje na bilo kakav sporazum o miru koji bi predviđao formiranje etnički čistih teritorija i podjelu na isključivo etničkoj bazi.

Posebno se u periodu samog početka agresije na Bosnu i Hercegovinu u javnom prostoru jasno ukazuje na nespojivost etničkog kriterija pri kreiranju unutrašnjeg uređenja države. „Ono što BiH zaista konstituiše, ono što je njena supstanca, to nisu nacije/narodi, već su to njeni ljudi, GRAĐANI. Formula o tri konstitutivna dijela je tempirana bomba u temeljima ove države. Dobrim dijelom izgovori zagovaranja $\mathrm{BiH}$ kao tronacionalne države dolaze iz mita o nacionalnoj državi. Ideja nacionalne države je kuga koja Bosnu i Hercegovinu zatire. Njoj treba suprostaviti ideju građanske države i to treba biti ratni cilj onih koji se bore za dobro BiH i njenih ljudi“ (Grebo, 1992:1).

Ideja da Bosnu i Hercegovinu konstituiraju narodi a ne građani potiče od onih koji su, povlačeći paralelu između Jugoslavije i BiH, tvrdili da, ukoliko BiH ne bude podijeljena između Srbije i Hrvatske ili se ne uspije priključiti velikoj Srbiji, treba je, po uzoru na SFRJ, konstituirati na principu konstitutivnih naroda. „Ideja o konstitutivnosti naroda u Bosnu je došla izvana i ciljala je na međunarodnopravno legitimiranje konstitutivnih naroda koji bi imali svoje teritorijalno oblikovane paradržavne tvorevine s mogućnošću otcjepljenja od Bosne i Hercegovine i priključenja Srbiji, odnosno Hrvatskoj“ (Filandra, 2012:251). Na samom početku agresije na $\mathrm{BiH}$, ideja 
o konstitutivnosti naroda je za cilj imala, kako Filandra zaključuje, da legalizira i legitimira tada uspostavljene paradržavne tvorevine bosanskih Srba i Hrvata da bi kasnije, ista teorija o konstitutivnosti naroda dobila drugačije značenje. Izraz „konstitutivni narodi“ dobija nešto drugačiju konotaciju 2000. godine nakon donošenja odluke Ustavnog suda Bosne i Hercegovine ${ }^{8}$ kojom se zaključuje da pojam „konstitutivnost naroda“ obuhvata i načelo kolektivne jednakosti sve tri etničke skupine.

U preambuli Dejtonskog mirovnog sporazuma 1995. godine stoji da „Bošnjaci, Hrvati i Srbi, kao konstitutivni narodi u zajednici sa ostalima i građani Bosne i Hercegovine ovim uređuju Ustav Bosne i Hercegovine“ što ukazuje na ravnopravni status tri naroda ali i svih građana $\mathrm{BiH}$. S druge strane, entitetske vlasti nisu svoje ustave usaglasili sa Dejtonskim mirovnim sporazumom, odnosno sa Ustavom BiH. Srpsko građansko vijeće je, na tom tragu, uz podršku Hrvatskog narodnog vijeća, Vijeća kongresa bošnjačkih intelektualaca i Asocijacije nezavisnih intelektualaca „Krug 99“, uputilo inicijativu Ustavnom sudu Bosne i Hercegovine da donese odluku koja bi grantirala ustavnu ravnopravnost sva tri konstitutivna naroda na cijelom teritoriju države 9 . Političke stranke su u odnosu na ovu inicijativu u principu zauzele ili protivan stav ili su bile suzdržane a rijetke su bile one koje su dale svoju podršku za postizanje konstitutivnosti naroda na prostoru cijele države ${ }^{10}$. Provođenje Odluke Ustavnog suda Bosne i Hercegovine uslijedilo je 2001. godine,odnosno nakon usvajanja amandmana na Ustav Federacije $\mathrm{BiH}$ i

\footnotetext{
${ }^{8}$ Ustavni sud BiH, odluka U 5/98, tačka 60, 1.VII 2000. Ustavni sud Bosne i Hercegovine je 30. juna i 1. jula 2000. godine donio Odluku o konstitutivnosti naroda koja nalaže jednakost u pogledu ostvarivanja ljudskih prava i sloboda za sve građane na nivou Bosne i Hercegovine. Vidjeti: Konstitutivnost naroda u Bosni i Hercegovini: zbornik dokumenata Srpskog građanskog vijeća - pokret za ravnopravnost BiH 1992-2001 godine, Srpsko građansko vijeće - pokret za ravnopravnost Bosne i Hercegovine, Sarajevo, 2001., str. 181 - 182

${ }^{9}$ „Prvobitnu inicijativu za postizanje konstitutivnosti srpskog naroda u Federaciji Bosne i Hercegovini pokreće Srpsko građansko vijeće na svojoj Osnivačkoj skupštini u Sarajevu, 27. marta 1994. godine. Inicijativa je pokrenuta u obliku amandmana na Ustav Federacije BiH. Srpsko građansko vijeće, nakon potpisivanja Dejtonskog mirovnog sporazuma, zapravo 1997. godine, proširuje svoju inicijativu o postizanju konstitutivnosti naroda, na temelju Deklaracije o ljudskom pravu na političku i nacionalnu ravnopravnost . Ovom deklaracijom započeta je realizacije ideje o postizanju konstitutivnosti srpskog naroda u Federaciji BiH i bošnjačkog i hrvatskog u Republici Srpskoj u postdejtonskom vremenu“ (Pejanović, Mirko (1999) Bosansko pitanje i Srbi u Bosni i Hercegovini, Sarajevo: Bosanska knjiga, str. 296 i 299, 300, 301 i 302).

${ }^{10}$ Srpska demokratska stranke i Hrvatska demokratska zajednica su svoje protivljenje ovoj ideji izrazile i na taj način što su izvršile uticaj na sudije Ustavnog suda BiH i reda srpskog i hrvatskog naroda da ne glasaju za Odluku Ustavnog suda $\mathrm{BiH}$ o konstitutivnosti naroda. U Federaciji BiH konstitutivnost naroda u oba entiteta podržale su Stranka demokratske akcije, Socijaldemokratska partija, Hrvatska seljačka stranka, Nova hrvatska inicijativa kao i sve stranke iz tadašnjeg opozicionog bloka (Pejanović, 2005:257-258).
} 
Ustav Republike Srpske i parlamentarnih izbora 2002. godine. Na taj način su započeti procesi koji će osigurati ukidanje etničke diskriminacije oko 1300 000 građana Bosne i Hercegovine, Srba u Federaciji BiH a Bošnjaka i Hrvata u Republici Srpskoj, stvaranje pravne osnove za jednaku zaštitu ljudskih prava u multietničkom društvu te se omogućuju rješenja koja vode ka integraciji putem osnaživanja uloge i nadležnosti organa države Bosne i Hercegovine (Pejanović, 2005:245). Nakon nemogućnosti da se osigura parlamentarna većina za usvajanje amandmana u entitetskim ustavima u Parlamentu FBiH i Narodnoj skupštini RS-a uslijedila je Odluka visokog predstavnika međunarodne zajednice o proglašenju amandamana o konstitutivnosti naroda i $\mathrm{u}$ Federaciji BiH i Republici Srpskoj. Provođenjem ove Odluke došlo je do izmjena koje se odnose na izbor potpredsjednika entiteta, članova entitetskih vlada i imenovanja sudija vrhovnih sudova u entitetima na način da se u tim institucijama obezbijedi do tada diskriminiranog konstitutivnog naroda. Međutim, izvan primjene amandmana o konstitutivnosti naroda su ostale republička i općinske uprave, javne ustanove i javna preduzeća, najprije u Republici Srpskoj a onda i u Federaciji BiH. Ako se uzme u obzir da su ovo institucije i preduzeća, koja broje najveći broj uposlenih, onda dolazimo do zaključka da je struktura zaposlenih još uvijek dominantno mononacionalna. U Brčko distriktu, za razliku od entiteta, u potpunosti se primjenjuje ustavni princip ravnopravnosti i razmjerne zastupljenosti naroda.

Evropski sud za ljudska prava je također razmatrao diskriminatorni odnos prema kategoriji „ostalih“ u BiH u predmetu Sejdić i Finci protiv Bosne i Hercegovine a kasnije i u nekoliko drugih predmeta. Sud je u ovom predmetu donio zaključak da je aplikantima, Dervi Sejdiću i Jakobu Finciju, učinjena diskriminacija budući da im je onemogućen izbor u Predsjedništvo BiH kao i u Dom naroda Parlamentarne skupštine $\mathrm{BiH}^{11}$ zbog njihove rasne/etničke pripadnosti ${ }^{12}$. Danas, nakon jedanaest godina od donošenja presude, možemo konstatirati da presuda, prema kojoj se trebao korigirati Ustav kao i Izborni zakon Bosne i Hercegovine u smislu ukidanja diskriminatornih odredbi, još nikada nije implementirana.

\footnotetext{
${ }^{11}$ Sud je 22. decembra 2009. godine donio presudu u kojoj se navodi da je prekršen stav 14. u vezi sa članom 3. protokola br.1. koji se odnosi na nemogućnost aplikanata da se kandiduju na izborima za Dom naroda $\mathrm{BiH}$ te povrijeđen član 1. Protokola br. 12 zbog nemogućnosti aplikanata da se kandiduju za Predsjedništvo BiH.

${ }^{12}$ Diskriminaciju po etničkoj osnovi Sud smatra oblikom rasne diskriminacije.
} 


\section{Zaključna razmatranja}

Koncept „konstitutivnih naroda“ je doživio temeljnu transformaciju te je vremenom postao cilj a ne sredstvo. Postao je „sama suština države i društva u Bosni i Hercegovini““ te je njegov značaj takav da zamagljuje njegovu očiglednu ,kontradiktornost sa principom zabrane diskriminacije u ostvarivanju ljudskih prava ..." (Nadaždin Defterdarević, 2014:84). Pored toga, budući da se insistira na etničkom izjašnjavanju, otvoren je veliki prostor za manipulaciju tom kategorijom.

Iako je Evropski sud za ljudska prava u svojim presudama naglasio kako u Ustavu Bosne i Hercegovine kao i u Izbornom zakonu postoji diskriminacija prema pripadnicima nacionalnih manjina, odnosno onih koji se ne izjašnjavaju kao građani, te presude još nikada nisu implementirane. I dalje je za navedene kategorije stanovništa nemoguće da se kandidiraju na određene političke funkcije a čak se može kazati da se u javnom prostoru javljaju nove tendencije da se bosanskohercegovački politički prostor dodatno dezintegrira i etnicizira.

\section{Literatura}

Begić, I. Kasim (1997) Bosna i Hercegovina od Vencove do Daytonskog sporazuma, Sarajevo: Izdanje Bosanska knjiga i Pravni centar Fonda otvoreno društvo Bosne i Hercegovine Filandra, Šaćir (2012) Bošnjaci nakon socijalizma: o bošnjačkom identitetu u postjugoslavenskom dobu, Sarajevo: BZK Preporod, Zagreb: Synopsis

Grebo, Zdravko (1992) „Ratni ciljevi“, Oslobođenje, Sarajevo, 14. oktobar 1992. godine

Grujić, Branislav: Rječnik latinsko-srpskohrvatski, Cetinje: izdanje Obod

Grujić, Branislav: Rječnik latinsko-srpskohrvatski, Cetinje: izdanje Obod

Ibrahimagić, Omer (1995) Bosna i Bošnjaci - narod koji su trebali nestati, Sarajevo: Svjetlost Mujkić, Asim (2007) Mi, građani Etnopolisa, Sarajevo: TKD Šahinpašić

Nadaždin Defterdarević, Mirjana (2014) Ljudska prava u Bosni i Hercegovini - pretpostavke uspješne realizacije, u zborniku radova sa Međunarodne naučne konferencije „Javni i privatni aspekti nužnih pravnih reformi u BiH: Koliko daleko možemo ići?“, str. 73 - 91

Osmojezični enciklopedijski rječnik, knjiga 2, Zagreb: Leksikografski zavod „Miroslav Krleža“, 1995. godina

Pehar, Antonio (2014) Utemeljenje Bosne i Hercegovine na načelima ustavnog patriotizma, Političke analize, Vol. 5. No. 19, str. 9 - 13

Pejanović, Mirko (1999) Bosansko pitanje i Srbi u Bosni i Hercegovini, Sarajevo: Bosanska knjiga

Pejanović, Mirko (2005) Politički razvitak Bosne i Hercegovine u postdejtonskom periodu, Sarajevo: Šahinpašić, Sarajevo

Pobrić Nurko (2016) Federalizam i konsocijacija za BiH - osvrt na jednu studiju, Fondacija Centar za javno pravo, str. 1-19

Seizović, Zarije (2012) Etno - mobilizacija i institucionalna diskriminacija u Bosni i Hercegovini, kratak povijesno - pravno - politološki diskurs, u zborniku Politička participacija 
u BiH, priređivači Arijana Aganović i Saša Gavrić, edicija BH politika, Sarajevo: Sarajevski otvoreni centar, str. 11-37

Trnka, Kasim (2000) Konstitutivnost naroda: povodom odluke Ustavnog suda Bosne i Hercegovine o konstitutivnosti Bošnjaka, Hrvata i Srba i na nivou entiteta, Sarajevo: Vijeće Kongresa bošnjačkih intelektualaca

Vukoja, Ivan, Sitarski, Milan (ur.) (2016) Bosna i Hercegovina, federalizam, ravnopravnost i održivost: Studija preustroja BiH u cilju osiguranja institucionalne jednakopravnosti konstitutivnih naroda, Mostar: Institut za društveno - politička istraživanja

\section{Dokumenti}

Ustav SFRJ iz 1974. godine, Osnovna načela, poglavlje I, „Službeni list SFRJ“ br. 3/74 Odluka Ustavnog suda BiH, U 5/98, tačka 116, 1.VII 2000.

Ustav Bosne i Hercegovine

Ustav Federacije Bosne i Hercegovine

Ustav Republike Srpske

\section{The Electoral System of Bosnia and Herzegovina and the Ethnicization of the B\&H Political Space}

\section{Conclusion}

The concept of "constituent peoples" has passed through a fundamental transformation and over time has become a goal rather than a means. It has become "the very essence of the state and society in Bosnia and Herzegovina" and its significance is such that it obscures its obvious "contradiction with the principle of non-discrimination in the exercise of human rights ...” (Nadaždin Defterdarević, 2014: 84). Since the ethnic declaration is insisted on, a large space is open for manipulating this category.

Although the European Court of Human Rights emphasized in its judgments that in the Constitution of Bosnia and Herzegovina as well as in the Election Law there is discrimination against members of national minorities, ie those who do not declare themselves as citizens, these judgments have never been implemented. It is still impossible for the above categories of the population to run for certain political positions, and it can even be said that new tendencies are emerging in the public space to further disintegrate and ethnicize the Bosnian political space. 